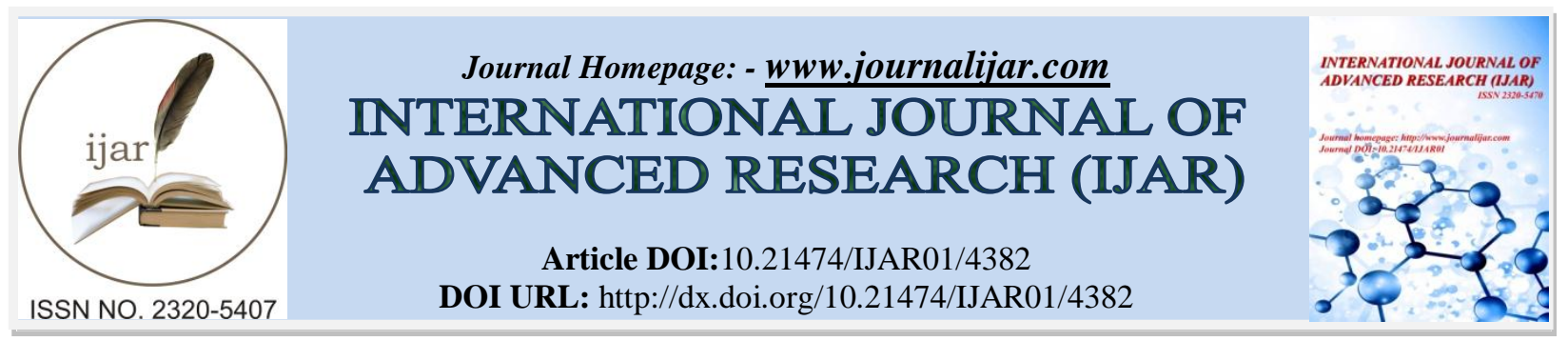

RESEARCH ARTICLE

\title{
ROLE OF ASHMARIHARAKWATHA\&VARUNA-SHIGRUKWATHA IN MANAGEMENT OF MOOTRASHMARI (UROLITHIASIS).
}

\section{Dr. Priyanka Chauhan ${ }^{1}$ and Dr. S.K. Gupta ${ }^{2}$.}

1. 3rd year M.S. Ayu, Department of Shalya tantra, IPGT \& RA, GAU, Jamnagar.

2. Professor \& Head, Department of Shalya tantra, IPGT \& RA, GAU, Jamnagar.

\section{Manuscript Info}

Manuscript History

Received: 02 april 2017

Final Accepted: 04 june 2017

Published: june 2017

Key words:-

Ashmari, Urinary Stone, Urolithiasis,

Ashmarihara Kwatha, Ashmarihara Ghanvati.

Copy Right, IJAR, 2017,. All rights reserved.

\section{Introduction:-}

As per classics Ashmari is included in Ashtomahagada (Eight dreadful diseases) due to its notoriousnature and reluctant to cure. Description of Ashmari is found in almost all Samhitas of Ayurveda either as a type of Mutraghata $(\text { Charaka })^{\mathrm{ii}}$ or as a separate disease (Sushruta) ${ }^{\mathrm{iii}}$.

Sushruta, has described Mootrashmari first timein details including etiological factors, classifications, symptomatology, pathophysiology, complication and its management by drugs, parasurgical therapy as well as surgical management in a scientific manner. The process of urinary stone formation as described by Sushruta is as follows-

\section{तत्रासंशोधनशीलस्यापथ्यकारिण: प्रकुपित: श्लेष्मामूत्रसंपृक्तोअनुप्रविश्यबस्तिमश्मरींजनयति $\mathrm{I}^{\mathrm{iv}}$}

The KaphaDosha of a person, who neglects Samshodhana (internal channels of his organs) or is in the habit of taking undesirable and unsuitable (Apathyakari) foods, enraged and aggravated by its own exciting causes and reaches to the urinary bladder where it becomes saturated with the stone forming substances and gives rise to formation of concretion or gravels which pass through the urine. So, an exuberance of deranged KaphaDosha should be taken in to the consideration as the underlying cause of Mootrashmari.

Ashmari isa disease having its own identity equally in both sciences, Ayurveda as well as Modern and afflicting about $2 \%$ of population. It is more common in male than female. Although there is great advancement has been made in the field of modern science yet still there is a need for a specific line of treatment which is least or noninvasive and affordable.

Sushruta has been described various medicines and surgical intervention for Ashmari. Surgical treatment has to be undertaken only on failure of conservative treatment and when death becomes inevitable. As per Ayurveda medicinal treatment includes use of various Ghrita, Kwatha, Churna, KsharaDravyas etc ${ }^{\mathrm{v}}$. Among those, Kwatha are used predominantly because they are mostly having Mutrala and Bhedana properties 
In modern science the best possible treatment for urinary calculus is use of various drugs to correct involved pathologies and use of diuretics as well as surgical intervention including open surgery, per cutaneous techniques, ESWL $^{\text {vi }}$ etc. But even after surgery there are high chances of recurrence because urinary stones have peculiar tendency of recurrence.

Now a day's everybody is in state of hurry. This in turns ends with abnormal food habit, less intake of water, lots of perspiration which increases chance of getting stone. The consumption of food materials like milk (High in calcium), Leafy vegetables, tomatoes (High in oxalate), meat and non-veg food (High in protein content) increases the incidence of renal calculus ${ }^{4}$. In Gujarat, particularly in Saurashtra region the incidence of Mootrashmari is very high due to high mineral content of water and hot climate. Approximately $30 \%$ patients of urinary disorders are found suffering from urolithiasis.

\section{Material and methods:-}

Selection of Patients, Grouping and Posology:

Patients having signs and symptoms of Mootrashmari (Urolithiasis) were selected irrespective of sex, religion, occupation from OPD and IPD of Shalya Tantra, I.P.G.T. \& R.A. Hospital, Jamnagar and from special camps organized time to timeand randomly categorized into 3 groups.

Table 1:-

\begin{tabular}{|l|l|l|l|l|l|l|}
\hline Groups & $\begin{array}{l}\text { No. of } \\
\text { patients }\end{array}$ & Formulation & Route & Dose & $\begin{array}{l}\text { Time } \\
\text { (After meal) }\end{array}$ & Duration \\
\hline $\begin{array}{l}\text { Group A } \\
\text { (Trial group) }\end{array}$ & 15 & $\begin{array}{l}\text { Varuna-shigru } \\
\text { Kwatha }\end{array}$ & Orally & $40 \mathrm{ml}$ & Twice a day & 30 days \\
\cline { 5 - 6 } & $\begin{array}{l}\text { Yava Kshara } \\
\text { (Prakshep) }\end{array}$ & & $2 \mathrm{gm}$ & & \\
\hline $\begin{array}{l}\text { Group B } \\
\text { (Control group) }\end{array}$ & 15 & Ashmarihara Kwatha & Orally & $40 \mathrm{ml}$ & Twice a day & 30 days \\
\hline $\begin{array}{l}\text { Group C } \\
\text { (Trial group) }\end{array}$ & 15 & $\begin{array}{l}\text { Ashmarihara Kwatha } \\
\text { Ghanvati }\end{array}$ & Orally & $500 \mathrm{mg}$ & Twice a day & 30 days \\
\hline
\end{tabular}

(20 gm raw material was taken for preparation of $40 \mathrm{ml} K$ watha and $20 \mathrm{gm}$ raw material was taken for preparation of $500 \mathrm{mg}$ Ghanvati)

Procurement of Drug:-

All drugs were procured from the pharmacy of IPGT \& RA, GAU, Jamnagar.

\section{Research Proforma:-}

Special research proforma was prepared on the basis of signs and symptoms of Ashmari as well as the features of urolithiasis described in the texts.

Criteria for selection of patients:-

Inclusion criteria:-

- Age -16 to 70 years.

- Pain in the renal angle\& loin region, radiating towards groin.

- Renal \& Bladder Stonesize up to $20 \mathrm{~mm}$

- Ureteric Stonesize up to $10 \mathrm{~mm}$

- Radiographic and / or USG evidence of the stone.

- Crystals of stone.

- Urolithiatic patients with controlled Hypertension \& Diabetic Mellitus.

Exclusion Criteria:-

- Renal failure.

- Gross Hydronephrosis.

- Acutepain abdomen.

- Cases which requires surgical intervention.

- Severe Haematuria. 
- Renal \& Bladder Stone size> $20 \mathrm{~mm}$

- Ureteric Stonesize> $10 \mathrm{~mm}$

- Known cases of Malignancy.

- Known cases of Tuberculosis.

- Known cases of HIV, VDRL \& Hepatitis-B positive.

Diagnostic Criteria:-

Patients were diagnosed on the basis of clinical features, physical examination, laboratory investigation and radiological evidences.

\section{Laboratory investigation:-}

Serum Creatinine, Serum Calcium, Uric acid, Urine examination, X-ray for KUB region and USG for abdomen \& Pelvis were carried out before and after treatment whereas $\mathrm{Hb} \%$, CBC, ESR and FBS were carried out before treatment only.

\section{Research Design:-Open Randomized Clinical Trial}

\section{Assessment Criteria:-}

Assessment was done on the basis of relief in signs, symptoms by scoring pattern \& laboratory and radiological findings.

Details of the scores adopted for the chief signs and symptoms ${ }^{\text {vii }}$ (before and after treatment) in the present study were as follows -

\section{Subjective Criteria:-}

\section{Pain}

- No pain

- Bearable pain, no medication

- Bearable pain and require oral medication

- Unbearable pain and require injectable medication

Burning micturition:-

- No burning micturition

- Occasional burning micturition

- Regular burning micturition, medicine not require

- Regular burning micturition, required medication-

$\begin{array}{ll}- & 0 \\ - & 1 \\ - & 2 \\ - & 3\end{array}$

Dysuria:-

- No dysuria

- Occasional dysuria

- Regular dysuria, medicine not require

- Regular dysuria, require medication

$\begin{array}{ll}- & 0 \\ - & 1 \\ - & 2 \\ 3 & \end{array}$

Haematuria:-

- No haematuria

- Smoky urine

- Blackish urine

- Bright red urine

$\begin{array}{ll}- & 0 \\ - & 1 \\ - & 2 \\ - & 3\end{array}$

Frequency of micturition (in 24 hours):-

- Up to 6 times

- 7-9 times

- 10-12 times

- >12 times

$\begin{array}{ll}- & 0 \\ - & 1 \\ - & 2 \\ - & 3\end{array}$




\section{Objective Parameters:-}

Size of stone:-

- No change

- Increase

- Decrease

$\begin{array}{lr}- & 0 \\ - & +1 \\ - & -1\end{array}$

Number of stones:-

- No change $\quad-\quad 0$

- Increase $\quad-\quad$ +

- Decrease $\quad-\quad-1$

Criteria for overall assessment of therapy:-

Cured

Marked improvement $\quad: \quad 60-<79 \%$ relief in sign and symptoms

Moderateimprovement $\quad$ : $\quad 40-<59 \%$ relief in sign and symptoms

Mild improvement $\quad$ : $\quad 20-<39 \%$ relief in sign and symptoms

No improvement $\quad$ : $\quad<20 \%$ relief in sign and symptoms

Follow up:-

After completion of treatment for 1 month, all the patients were instructed to visit for regular follow-up at fifteen days interval for the period of 1 month (30 days). During this follow up period patients were examined for the recurrence of either signs and symptoms of stones.

Ethical Clearance:-

The study was approved by the Institutional Ethics Committee (Ref. No.PGT/7-A/Ethics/2014-15/ 1538 Dt. 02/09/2014)

\section{CTRI Registration:-}

The study was registered with CTRI (Reg. No. CTRI/2016/01/006563)

Informed written Consent:-

It was taken from each patient in starting of the study.

\section{Observation:-}

Total 48 patients were registered, 16 in each group and 41 patients were completed the treatment. 13 patients in group A, 14 patients each in group B and C were completed the treatment. 3 patients in group A, 2 Patients each in group $\mathrm{B}$ and group $\mathrm{C}$ were discontinued the treatment due to their personal reasons.

Table 2:- All Observations and their percentage.

\begin{tabular}{|c|c|c|c|}
\hline Observation & Percentage of patient & Observation & Percentage of patient \\
\hline Age group (26-40 yrs) & $43.75 \%$ & Asamshodhanasheela & $77.08 \%$ \\
\hline Males & $68.75 \%$ & Guru Ahara & $77.08 \%$ \\
\hline Females & $31.25 \%$ & Snigdha Ahara & $75.00 \%$ \\
\hline Occupation Service & $31.25 \%$ & Madhura Ahara & $47.92 \%$ \\
\hline wives & $25.00 \%$ & Mamsa Ahara & $45.83 \%$ \\
\hline Higher middle class & $52.08 \%$ & Shita Ahara & $41.67 \%$ \\
\hline Vishamashana & $31.25 \%$ & Apathya sevana & $41.67 \%$ \\
\hline Adhyashana & $37.50 \%$ & Mutra Vegavarodha & $27.08 \%$ \\
\hline U2 litres water intake & $50.00 \%$ & Increased Frequency of & $93.75 \%$ \\
\hline Up to 1.5 litres water & $10.41 \%$ & micturition & $35.41 \%$ \\
\hline Addiction of tobacco & $29.17 \%$ & Mutradhara sang & $37.50 \%$ \\
\hline Addiction of smoking & $22.92 \%$ & Bilateral renal stones & $81.25 \%$ \\
\hline Divaswapna & $75.00 \%$ & Left renal stones & $47.91 \%$ \\
\hline Scanty micturition & $18.75 \%$ & $29.16 \%$ \\
\hline
\end{tabular}




\begin{tabular}{|c|c|c|c|}
\hline Sadaha Micturition & $81.25 \%$ & Right renal stones & $20.83 \%$ \\
\hline Mutra-krichchhata & $39.58 \%$ & Ureteric stones & $16.66 \%$ \\
\hline Sasula Micturition & $37.50 \%$ & Bladder stones & $06.25 \%$ \\
\hline Vata Kapha prakriti & $43.75 \%$ & \multirow{2}{*}{ Positive X-ray Findings } & \multirow{2}{*}{$45.83 \%$} \\
\hline Ushna Ahara Sevana & $79.17 \%$ & \\
\hline
\end{tabular}

\section{Results:-}

Group A was showing statistically highly significantresults in pain (Vedana), Mutradhara Sanga (Interrupted urine flow) and burning micturition. Statistically insignificant results were observed in increased frequency of micturition. Group B showed statistically highly significantresults in pain (Vedana), Mutradhara Sanga (Interrupted urine flow), increased frequency of micturition and burning micturition whereas Group $\mathrm{C}$ showed statistically highly significantresults in pain (Vedana), and burning micturition; and statistically significant results were observed in Mutradhara Sanga (Interrupted urine flow), increased frequency of micturition. On comparison between Group A and B there was significant difference observed in Interrupted urine flow (Mutradharasang) whereas on comparison between Group B and C there was significant difference was observed in pain.

Table 3:- Effect of therapy on size of stone:

\begin{tabular}{|c|c|c|c|c|c|c|c|c|c|}
\hline Group & \multirow{2}{*}{ PARAMEETER } & \multicolumn{2}{|c|}{ Mean } & Diff. & \% Change & DF & 't' & P & S \\
\cline { 3 - 7 } & & BT & AT & & & & & & \\
\hline Group A & STONE SIZE & 15.60 & 14.077 & 1.523 & 9.762 & 12 & 0.947 & 0.362 & IN \\
\hline Group B & STONE SIZE & 9.471 & 5.107 & 4.364 & 46.078 & 13 & 4.143 & 0.001 & HS \\
\hline Group C & STONE SIZE & 10.764 & 7.614 & 3.150 & 29.28 & 13 & 2.434 & 0.030 & S \\
\hline
\end{tabular}

Table 4:-Overall Effect of Therapy on Types of Stone as per site: $(n=41)$

\begin{tabular}{|c|c|c|c|c|c|c|}
\hline \multirow[t]{2}{*}{ Variety } & \multicolumn{2}{|c|}{ Group A (VSK) } & \multicolumn{2}{|c|}{ Group B (AHK) } & \multicolumn{2}{|c|}{ Group C (AHKG) } \\
\hline & $\begin{array}{l}\text { No of } \\
\text { Stone }\end{array}$ & Effect in \% & No of Stone & Effect in \% & No of Stone & Effect in \% \\
\hline $\begin{array}{c}\text { Kidney Stone total } \\
\text { (BT) }\end{array}$ & 24 & & 22 & & 26 & \\
\hline Expelled & 04 & $16.66 \%$ & 08 & $36.36 \%$ & 08 & $30.76 \%$ \\
\hline Decrease in size & 07 & $29.16 \%$ & 09 & $40.90 \%$ & 08 & $30.76 \%$ \\
\hline No change & 08 & $33.33 \%$ & 04 & $18.18 \%$ & 07 & $26.92 \%$ \\
\hline Increase in size & 05 & $20.83 \%$ & 01 & $04.54 \%$ & 03 & $11.53 \%$ \\
\hline $\begin{array}{c}\text { Ureteric Stone } \\
\text { total }\end{array}$ & Nil & & 02 & & 03 & \\
\hline Expelled & Nil & Nil & 02 & $100.00 \%$ & 02 & $66.66 \%$ \\
\hline $\begin{array}{l}\text { Decrease in } \\
\text { size }\end{array}$ & Nil & Nil & Nil & Nil & 01 & $33.33 \%$ \\
\hline No change & Nil & Nil & Nil & Nil & Nil & Nil \\
\hline Increase in size & Nil & Nil & Nil & Nil & Nil & Nil \\
\hline Bladder stone & 02 & Nil & Nil & Nil & Nil & Nil \\
\hline Expelled & Nil & Nil & Nil & Nil & Nil & Nil \\
\hline Decrease in size & 02 & $100.00 \%$ & Nil & Nil & Nil & Nil \\
\hline No change & Nil & Nil & Nil & Nil & Nil & Nil \\
\hline Increase in size & Nil & Nil & Nil & Nil & Nil & Nil \\
\hline
\end{tabular}

Table 5:- Overall assessment of therapy in all groups: Overall assessment is calculated by giving $70 \%$ weightage to the subjective parameters and $30 \%$ weightage to the objective parameters.

\begin{tabular}{|c|c|c|c|c|c|c|c|c|}
\hline \multirow[t]{3}{*}{ OverallAssessment } & \multicolumn{6}{|c|}{ Effect of Therapy } & \multirow[t]{3}{*}{ Total } & \multirow[t]{3}{*}{$\%$} \\
\hline & \multicolumn{2}{|c|}{$\begin{array}{c}\text { Group A } \\
(\mathrm{VSK}+\mathrm{YK})\end{array}$} & \multicolumn{2}{|c|}{ Group B (AHK) } & \multicolumn{2}{|c|}{$\begin{array}{l}\text { Group C } \\
(\text { AHKG) }\end{array}$} & & \\
\hline & $\begin{array}{c}\text { No. of } \\
\text { Patients }\end{array}$ & $\begin{array}{c}\text { Effect in } \\
\%\end{array}$ & $\begin{array}{c}\text { No. of } \\
\text { Patients }\end{array}$ & $\begin{array}{c}\text { Effect in } \\
\%\end{array}$ & $\begin{array}{c}\text { No. of } \\
\text { Patients }\end{array}$ & $\begin{array}{c}\text { Effect } \\
\text { in } \%\end{array}$ & & \\
\hline
\end{tabular}




\begin{tabular}{|c|c|c|c|c|c|c|c|c|}
\hline Cured & 02 & 15.38 & 05 & 35.71 & 03 & 23.07 & 10 & 24.39 \\
\hline $\begin{array}{c}\text { Marked } \\
\text { Improvement }\end{array}$ & 02 & 15.38 & 07 & 53.84 & 04 & 30.76 & 13 & 31.70 \\
\hline ModerateImprovement & 07 & 53.84 & 01 & 07.69 & 04 & 30.76 & 12 & 29.26 \\
\hline $\begin{array}{c}\text { Mild } \\
\text { Improvement }\end{array}$ & 01 & 07.69 & 00 & 00.00 & 02 & 15.38 & 03 & 07.31 \\
\hline $\begin{array}{c}\text { No } \\
\text { Improvement }\end{array}$ & 01 & 07.69 & 01 & 07.69 & 01 & 07.69 & 03 & 07.31 \\
\hline Total & 13 & 100.00 & 14 & 100.00 & 14 & 100.00 & 41 & 100.00 \\
\hline
\end{tabular}

Chart 1:- Overall Assessment of Therapy.

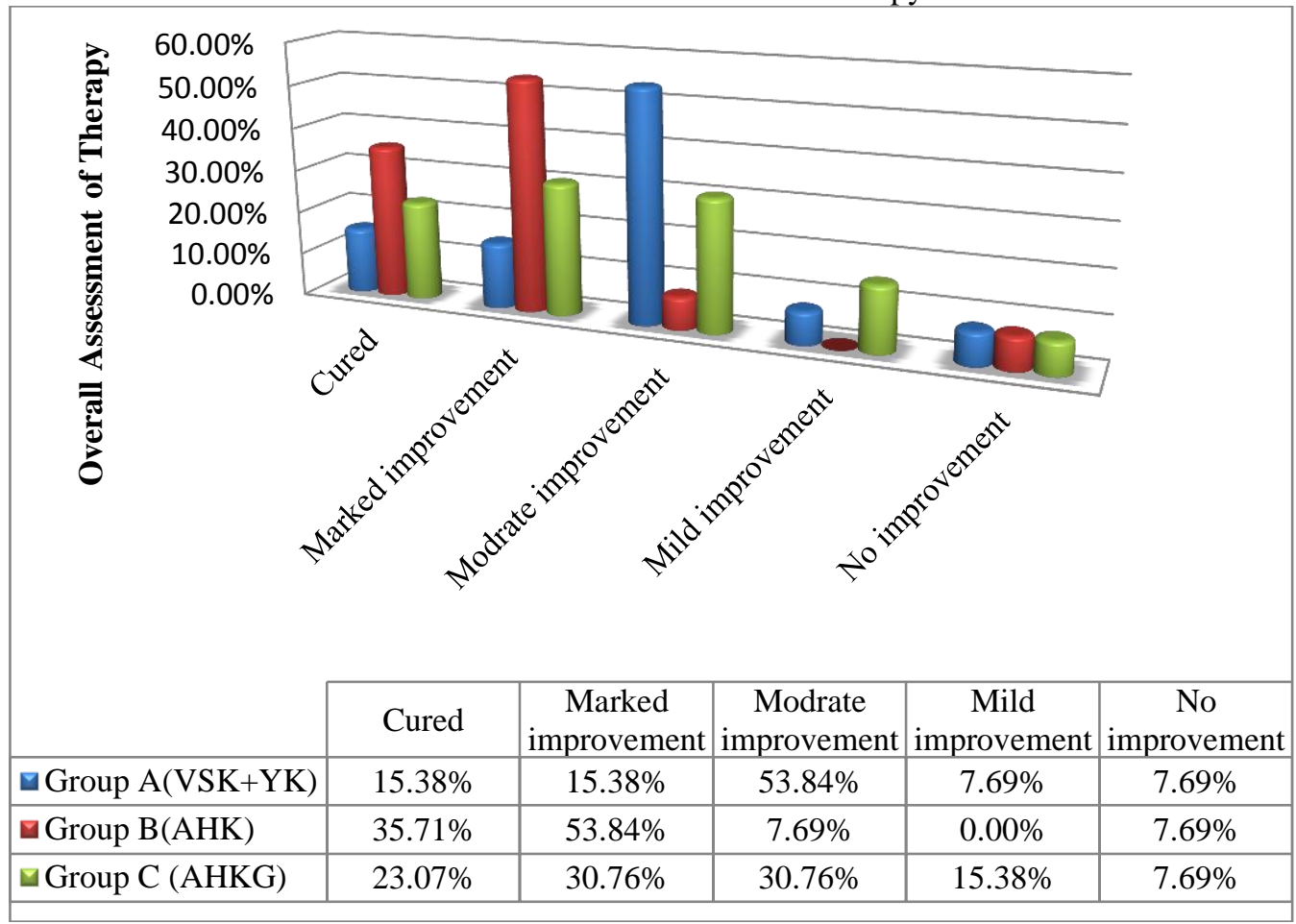

\section{Discussion:-}

Though Ashmari can occur at any age yet middle age group are more prone for occurrence of Ashmari ${ }^{\text {viii }}$. In females, stone formation is less because of low serum testosterone level ${ }^{\mathrm{ix}}$. Ashmari has no relation with religion, but this might be due to geographical dominance of Hindu population in Jamnagar and surrounding area of research place. Peoples who are in service spent maximum time in works place and ignore to take sufficient water and mostly they are the victim of irregular dietetic habit. Middle class peoples are mostly having stressful life and irregular dietary habits leads to vitiation of Agni and Doshas resulting in diseased condition. Up to 1.5 liters water intake is not sufficient for a normal person according to the climatic conditions of Saurashtra and causes over saturation of urine which leads to formation of Ashmari.

Tobacco can play role in the formation of urinary stone as data suggested. Divaswapna was found in $75.00 \%$ patients, it may increase the chances of Kapha Dosha Prakopa, whichis considered as an important Nidana of Ashmari ${ }^{\mathrm{X}}$. Quantity of micturition plays important role in Ashmari formation and due to scanty micturition crystalloids are not properly excreted through urine and lead to Ashmari formation. Amongst the Nidanas, Ushna Ahara Sevana, Asamshodhanasheela, Guru Ahara, Divaswapna, Snigdha Ahara, Madhura Ahara Sevana, Mamsa Sevana, Shita Ahara, Apathya sevana and Mutra Vegavarodha were played important role to develop Ashmari as data have suggested. These all are mentioned under Nidanas of Ashmari in Ayurveda and have definite role in formation of stone by causing vitiation of Doshas and Srotovaigunya. Asamshodhana and Apathya sevana are the 
chief causes of Ashmari as mentioned by Sushruta and these were found in almost all patients registered under this study $^{\mathrm{xi}}$.

Amongst all chief complaints of Ashmari, Vedana was found in $93.75 \%$ patients, burning micturition in $77.08 \%$ patients, Mutradhara Sanga in $37.50 \%$ patients, increased frequency of micturition in $35.41 \%$ patients. These all are the classical symptoms of Ashmari and indicates different stages of disease pathology. Maximum $47.91 \%$ patients showed bilateral renal stone, $29.16 \%$ patients showed only left renal stone and $20.83 \%$ patients have depicted right renal stone. Total $16.66 \%$ patients were sufferingfrom ureteric stones and $6.25 \%$ patients were sufferingfrom bladder stones in this study. It is because that stones are usually formed in kidneys which are the prime organs related to urine formation and excretion then stone (s) come into ureter with urine and finally go in to the bladder and urethra. Only those stones which do not pass through the tract due to bigger size may be held at some level of urinary passage and as per the level / site those are known as ureteric, vesical or urethral stone. In some cases independent stone formation can occur in individual organs.

$\mathrm{X}$-ray finding for presence of stone $45.83 \%$ cases was positive. It indicates that only radio-opaque stones can be detected by X-ray ${ }^{\text {xii }}$ and it is not suitable for diagnosing stones which are radiolucent.

Assessment of therapy on chief complaints between all groups:-

Ashmarihara Kwatha showedbetter results in cured category, marked improvement category and no improvement category. Ashmarihara Kwatha Ghanvati showed better result in moderate and mild improvement category. VarunashigruKwatha showed better result in marked improvement. AshmariharaKwathaGhanvati showed better results than Varuna-shigruKwatha. The Kwatha preparation is tedious job reported by patients while Ghanvati is ready to take, palatable and preferred by patients in comparison to Kwatha preparation and it also has probably same properties as found in AshmariharaKwatha.

Comparative Effect of Therapy on average size of stones:-

Ashmarihara Kwatha - Group B has shown better result on average size of stones than group B and C. It can be attributed to the Lekhana and Bhedana properties of Ashmarihara Kwatha which gave better result.

Overall effect of therapy on Subjective and Objective parameters:-

AshmariharaKwatha- Group B has shown better results in cured and marked improvement category whereas Group A showed better results in moderate improvement category and Group $\mathrm{C}$ has shown good result in mild improvement category.

Probable Mode of action of Varuna-shigru Kwatha:-

> Varuna has Tikta and Kashaya Pradhana Rasa, and Shigru has Tikta and Katu Pradhana Rasa, bothdrugshave Ushna Virya, Katu Vipaka and Vatakapha Shamaka properties.

$>$ By virtue of Mutrala, Bhedana and ShulaprashamanaKarma it helps to disintegrate the stones and expelled out from Mutravaha Srotasa.

Probable Mode of action of Yava Kshara:-

> Yava Kshara is having Shodhana, Lekhana, Bhedana, Pachana and Tridosha Shamaka properties, so it reduces the pain and it helped in removal of stone probably by reduction in size.

$>$ Yava Kshara also acts as Lekhana for the stone, acting mainly on Kapha Dosha.

$>$ It is alkaline in nature and soluble in water, so it counteracts the pathogenesis of stone formation by alkalizing acidic media of urine.

Probable Mode of action of Ashmarihara Kwatha /Ashmarihara Kwatha Ghanvati:-

$>$ Most of the ingredient have Tikta- Kashaya Pradhana Rasa, Laghu - Ruksha Guna, Shita Virya, Katu Vipaka and Vatakapha Shamaka properties and have Mutrala, Vedanasthapana, Anulomana and Bastishodhana Karma ${ }^{\text {xiii }}$.

$>$ It causes relief in symptoms of Ashmari by virtue of Vatakapha Shamaka, Vedanasthapana, Shothahara, Mutrala, Rasayana and Anulomana properties.

$>$ It helps in disintegration of Ashmari by Laghu, Ruksha Guna and Vatakapha Shamaka properties. 
$>$ It also corrects Agni by Pachana and Anulomana properties, therefore it prevents formation of Ama as well as Pachana of Ama Doshas and breaks the pathogenesis of Ashmari and helps to prevent further Ashmari formation.

\section{Conclusion:-}

After completion of one month treatment trial for Mootrashmari, AshmariharaKwatha has shown overall better result to cure the disease Ashmari in comparison to Varuna-shigruKwatha with YavaKshara whereas other doses form of AshmariharaKwatha i.e. AshmariharaKwathaGhanvati also showed better result over the VarunashigruKwatha and YavaKshara, but it was found less effective than AshmariharaKwatha dose form.

\section{References:-}

1. Shastriambikadatkaviraj, Shushrutsamhita, NidanSthan, page no. 240, Varanasi, 2005

a. Sushruta, Sushruta Samhita Sootrasthana 33/4, Page 144, with Nibandhasamgraha commentary of

b. Shri Dalhanacharya, edited by Vaidya Yadavaji Trikamji Ächarya Chaukhamba Surbharati Prakashana, Vaaranasi, reprint edition 2010. (Ibid 2)

2. Agnivesha, Charaka \& Dridabala, Charaka Samhitaa Chikitsaa Sthaana 26/36, page-599, with

a. Aayurveda Deepikaa commentary of Chakrapani edited by Vaidya Yadavaji Trikamji Ācharya,

b. Chaukhamba Surbhaarati Prakaashana, Vaaraanasi, reprint edition 2009.

3. Ibid 2, Sushruta Nidaana Sthaana 3/1, Page 276

4. 2, Sushruta Nidaana 3/4, Page 277

5. Ibid 2, Sushruta Chikitsaa Sthaana $7 / 27$, Page 436

6. S. Das, A concise textbook of Surgery, Chapter 49, Page 1080-1083, Published by Dr. S. Das, a. Kolkata, $6^{\text {th }}$ Edition 2010

7. a) S. Das, A concise textbook of Surgery, Chapter 49, Page 1074-1075, Published by Dr. S. Das,

a. Kolkata, $6^{\text {th }}$ Edition 2010.

b. b) Sushruta, Sushruta Samhitaa Nidaana Sthaana 3/7, Page 277, with Nibandhasamgraha commentary

c. of Dalhana, edited by Vaidya Yadavaji Trikamji Aachaarya, Chaukhamba Surbharati

d. Prakashana,Varaanasi, reprint edition 2010.

8. http://www.myoclinics.com

a. www.medicinenet.com

b. Peter Hughes, Kidney stones epidemiology, Nephrology 2007; 12, S26-S30

9. Ibid 11, Ashtaanga Samgraha Nidaana Sthaana 9/9, Page 376.

10. Ibid 2, Sushruta Samhitaa Nidaana Sthaana 3/4, Page 277

11. Ibid 3, Chapter 49, Page 1076

Anonymous (1999), The Ayurvedic Pharmacopoeia of India, edition $1^{\text {st }}$, Govt. Of India, Ministry of Health and Family welfare, Department of I.S.M. \& H., New Delhi, Part -I, Vol. -I, II, IV, V. 